\title{
When the quip hits the fan: What cartoon complaints reveal about changes in societal attitudes to race and ethnicity
}

\author{
Susan E. Foster \\ Independent Scholar \\ foster.gorbey@paradise.net.nz
}

\begin{abstract}
A study of editorial cartoons published over the last 40 years, that have been the subject of complaint to the New Zealand Press Council or the Race Relations Conciliator, Human Rights Commission, offers insight into changes in taste and societal attitudes. Offence can be taken not only over the message of the cartoon but at the way it is visually expressed. The focus of this paper is on a selection of complaints of racism and racial stereotyping which together track an increase in sensitivity to racism in society as well as the changes in the race or ethnicity of the alleged subjects of discrimination. Although the Press Council sets a high bar to protect freedom of expression, allowing scope to cartoonists to express very strong, even unpopular viewpoints, the growing diversity of society, with many new immigrants to New Zealand from countries where there is not the same tradition of provocative graphic satire, is raising new questions as to where the boundaries of acceptability lie. Further pressure on editors is being placed by the immediacy of condemnation via social media of cartoons considered offensive short-circuiting the slower, standard complaint procedures which afford time for thoughtful deliberation. Cartoons are considered to be "Opinion" and, although this visual comment must have some factual basis, their key value is being able to say what in other forms is unsayable. If this means reflecting racist attitudes within society, surely, it is better that such attitudes are expressed in order that they can be addressed.
\end{abstract}

Key words: racism; discrimination; offence; editorial cartoons; newspaper editors. 


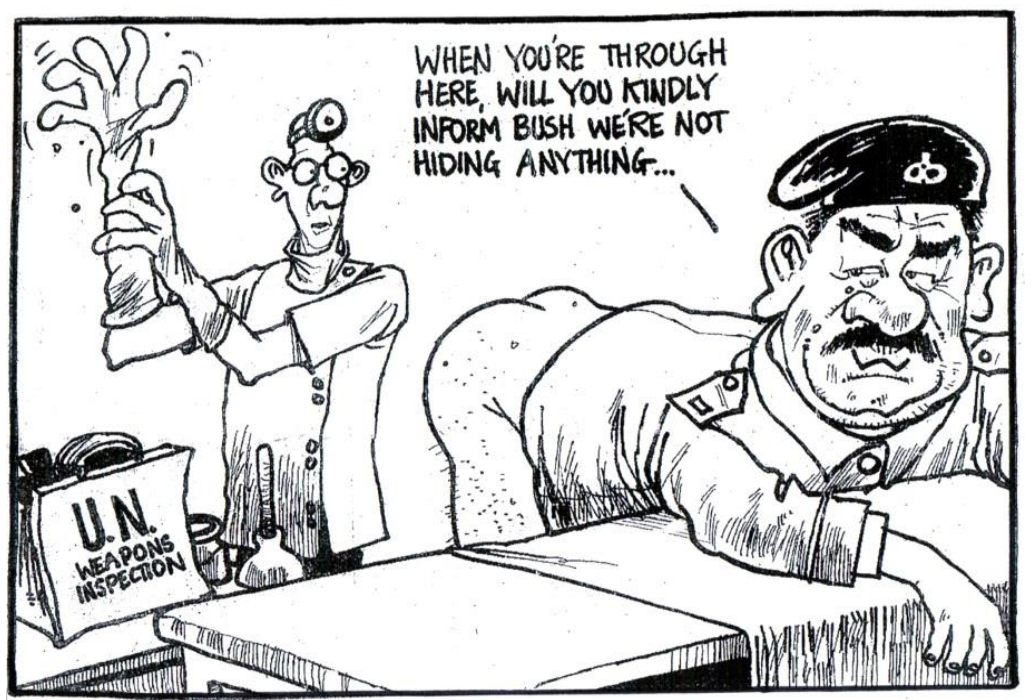

Figure 1. Tom Scott, The Dominion, 30 December 2002.

\section{Introduction}

\subsection{The language of cartooning}

A "disgusting" cartoon: this was the opinion of "a long-time subscriber" to The Dominion, Wellington's morning daily, regarding an editorial cartoon (see Figure 1) published on 30 December 2002. In a letter of complaint to the paper's editor, she asked how "such a cartoon could ever be published" (New Zealand Press Council 2003: Case 918). The cartoonist, Tom Scott, reacting to the news of the possibility of war with Iraq, based on unsubstantiated grounds, imagines the absurd lengths that United Nations inspectors might need to go to find the seemingly elusive weapons of mass destruction. The humour is in the shock and incongruity of the image. Heightened tension at the escalating crisis is relieved by the caricature of a dangerous dictator in undignified circumstances.

Cartoonists rely on their readers to understand the language of cartooning. For instance, the anal search of Iraq's President, Saddam Hussein, is not intended literally. Exaggeration, ridicule, caricature, metaphor, personification and stereotypes are just some of the cartoonist's graphic devices. In a response to the shocked complainant, The Dominion editor said that it had not been the intention of either the newspaper or the cartoonist to offend. He explained that cartoons were "often a tough graphic commentary on matters of public interest ... not always perceived by readers to be humorous", in fact, some can be "very satirical or scathing". The complaint, when subsequently referred to the New Zealand Press Council (NZPC), was not upheld; the Council re-stated a view expressed in a previous ruling "that newspapers have a wide discretion in the use of cartoons as vehicles for social-political comment" (NZPC 2003: Case 918). 


\subsection{The role of the New Zealand Press Council}

The Press Council, established in 1972 as a self-regulatory industry body, aims "to provide the public with an independent forum for resolving complaints involving the press". The Council is also concerned with promoting press freedom. In the "Preamble" which precedes a list of eleven principles, the Council states that: "Freedom of expression and freedom of the media are inextricably bound. There is no more important principle in a democracy than freedom of expression" (NZPC 2009).

A survey of Press Council cartoon complaints demonstrates that the Council has a clear understanding of the role and language of the editorial cartoon. In a ruling regarding the decision not to uphold a previous complaint against an Evening Post cartoon by Scott, published in December 1997, which depicted an automatic rifle with the caption "Take the drudgery out of blind carnage. Reach for a gun... it makes murder child's play", it commented that "it was not unreasonable to assume that readers would know not to take cartoons literally". Although appearing at the time of the trial of a 25-year-old with a history of mental illness, who killed six people at a central North Island ski lodge, the newspaper's assistant editor said "it was not intended literally as a comment on that incident ... [but] represented a timely observation on the wider issue of the availability of firearms and the ease with which they could be used to kill indiscriminately" (NZPC 1998: Case 684). The Council considered it "highly unlikely that any readers would imagine that they, or their children, were being urged by the Evening Post to settle disputes with a gun". It observed that "the use of cartoons to make satirical comment on the issues of the day was a well-established newspaper tradition", one which "must be strongly defended" as "long as the cartoons did not go too far" (NZPC 1998: Case 684).

\subsection{The role of the newspaper editor}

Who decides what is too far? The Press Council has stated that it "does not set itself up as an arbiter of taste or of what does or does not meet ever-changing and evolving notions of decency and acceptability". It notes that there are "lines which should not be crossed. But it is the prerogative of editors to make judgments ... in the interest of their newspaper" (NZPC 2006: Case 1055). As the editor of The Dominion noted, with regard to the publication of the Saddam Hussein cartoon (Figure 1), "ultimately the content [of a cartoon] is a matter for the editor's discretion" (NZPC 2003: Case 918). Likewise, Gavin Ellis, former editor-in-chief of the New Zealand Herald says: "You've got the final responsibility. And that should not be underrated ... only one person is legally responsible for all of the content of the newspaper ... not just the editorial content ... the advertising as well ... [and that] is the editor ..." (Ellis 2012).

The main reasons for an editor rejecting or requesting changes to a cartoon are if it was considered that the cartoon breached the boundaries of fairness or good taste or indulged in gratuitous racial or ethnic stereotyping or if there was a risk of litigation. But, as with newspaper content in general, it is even more the case with cartoons that it is difficult to predict the meaning the readership will take (Maharey 1990: 22). "For so graphic a medium" as Colin Seymour-Ure (2003: 231) writes "its appreciation is paradoxically private, for it depends heavily on the reader's imagination". 


\subsection{Research and objectives}

This paper arises from research into cartoons that have been the subject of complaint to newspaper editors, the Press Council and the Office of the Race Relations Commissioner at the Human Rights Commission (HRC). My study covers a 40-year period from the 1970s to 2013 and is supported by more than 150 hours of interviews recorded with editorial cartoonists and editors as part of an oral history project begun in 2004 and scheduled for completion by November 2015.

The majority of complaints fall within three broad subject areas: sex, race and religion. The focus of this paper is on a selection of complaints of racism and racial stereotyping. Included are complaints against cartoons addressing the issue of the Palestinian/Israeli conflict, variously condemned as anti-Semitic, anti-Israel or antiZionist, as these tend to span the second two categories given the definition of antiSemitism as "hostility towards or discrimination against Jews as a religious, ethnic, or racial group" (Merriam-Webster Dictionary 2014). Also, discussed is the Race Relations Commission's response to complaints over the re-publication of the Danish cartoons of Muhammad. While New Zealand cartoonists were involved only as far as their opinions were sought by the media, the level of public protest was a catalyst for opening the debate on the limits and responsibilities that adhere to the right to freedom of expression.

The Office of the Race Relations Conciliator was first established by the Race Relations Act 1971; subsequently the Act has been replaced by the Human Rights Act 1993, under which the office now operates. Unlike complaints to the Press Council, which are in the public domain, complaints to the HRC are treated as confidential under the Human Rights Act, the Privacy Act, the Official Information Act, and common law. So, research to date regarding complaints to this body has concentrated on newspaper reports and interviews with cartoonists and editors.

This paper explores a number of broad issues: what can a selection of complaints of racism in editorial cartoons published over the last 40 years tell us about changes in societal attitudes to race and ethnicity including the shifts in the race or ethnicity of those identified as being the subject of discrimination; the causes of offence whether related to the visual language of cartooning, the topic addressed and/or the provocative angle taken on an issue, or a lack of appreciation of the status of cartoons as "Opinion"; the impact on editorial decision-making of a heightened sensitivity to racism in society accompanied by a growth in ethnic diversity; the new pressures on editors with changing modes of complaint; and current threats to the principle of the editorial cartoonist's right to freedom of expression. 


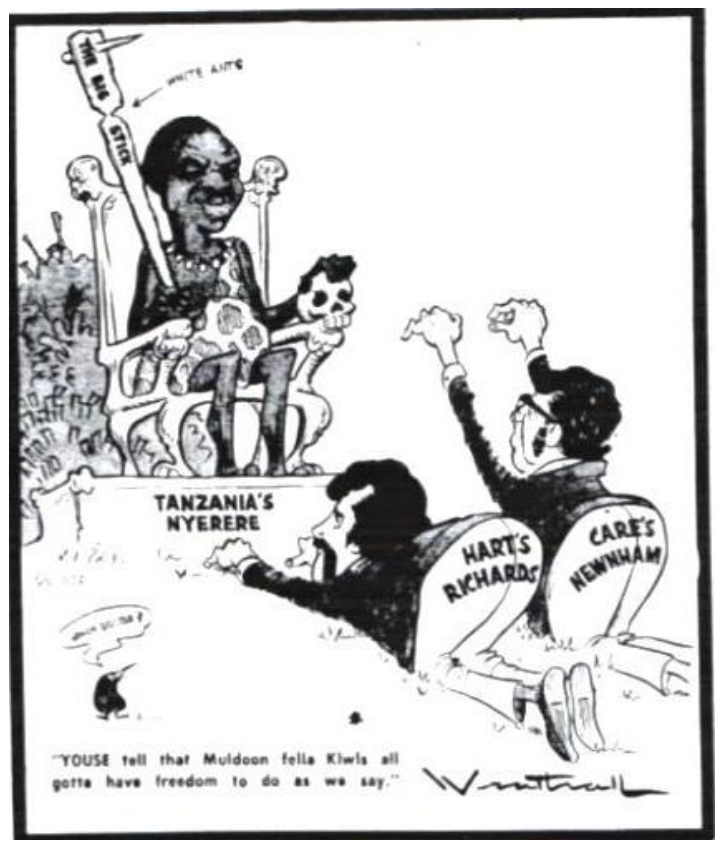

Figure 2. Bill Wrathall, Truth, 13 January 1976.

\section{Racism and racial stereotyping}

\section{1 "Black Africa": complaints of racial stereotyping}

Former Race Relations Conciliator, John Clark, defined a racial stereotype as "a form of prejudice ... used to judge a person's character, behaviour, intelligence and attitude on the basis of their race ... which can lead to rejection or acceptance of people because of their race or ethnicity" (Clark 1992-1995). The first cartoon complaint received by the Press Council was against New Zealand Truth for the publication of a cartoon (see Figure 2) considered "racialist because it ridiculed [Tanzanian President Julius Nyerere] as an African" in representing him "in some comic-opera African garb as a witch doctor or head hunter ... speaking some stage version of black man's English" (NZPC 1976: Case 69). The Western-educated Nyerere, described during his visit in 1974 as a leader of "great presence, charm and ability" (Cook 2012), is shown seated on a jungle throne, wearing only a cheetah skin and a necklace of teeth. In one hand, he clutches a skull; in the other, he wields "The Big Stick". An over-sized nail through the top of the latter threatens to inflict brutal injuries if it were not for evidence of "white ants", an allusion no doubt to the instability of Tanzania's singleparty, rule-by-force government. "Which doctor?" quips a small, everyman Kiwi in the foreground above the caption: "Youse tell that Muldoon fella Kiwis all gotta have freedom to do as we say" (NZPC 1976: Case 69).

The figures paying homage -Trevor Richards and Tom Newnham- represent two organisations at the forefront of protests against sporting contacts with apartheid South Africa: Halt All Racist Tours (HART) and Citizen's Association for Racial Equality (CARE). Both supported Tanzania's decision not to send the 1500-metrerecord-holder, Filbert Bayi, to race against New Zealander John Walker at an athletics meeting scheduled for January 1976 as a protest against New Zealand's continuance of sporting relations with South Africa including a planned All Black rugby tour for later that year (Richards 1999a: 136-137). In the previous year, opposition leader 
Robert Muldoon had made sporting contact with South Africa an election issue stating that "every New Zealander should be free ... to play sport with ... anyone in the world" (Templeton 1998: 120; Gustafson 2000: 232). With Truth's support for rugby tours to South Africa described as "predictable" (Yska 2010: 147), cartoonist Bill Wrathall is matching a common editorial line and reflecting the disappointment of many sports fans. The cartoon questions Nyerere's moral authority to dictate New Zealand's sporting policy given his own country's lack of democracy and respect for human rights.

The complaint was not upheld. The Council reasoned that a newspaper cartoon relies "primarily on ridicule ... and the art of caricature is likewise based on artistic exaggeration ... and that the cartoonist was entitled to give his impression (in graphical terms) of what he regarded as a backward country assuming too much on itself and being treated with reverence in the process". However, the Council did concede that the caption could be regarded "as offensive when related to President Nyerere" (NZPC 1976: Case 69). Highly regarded by former Prime Minister, Norman Kirk, Nyerere was the first African head of state to visit New Zealand (Richards 1999a: 115).

Stereotypes are a form of satirical shorthand, useful in conveying information about a character in a humorous way even when rude, clichéd and outdated. The lampooning of the leader of Tanzania as some sort of comic-book rendering of a wicked African potentate was intended to encapsulate the irony of the situation. It cannot be deduced necessarily from this drawing that the cartoonist was implying that all Tanzanians subscribe to primitive cultural practices.

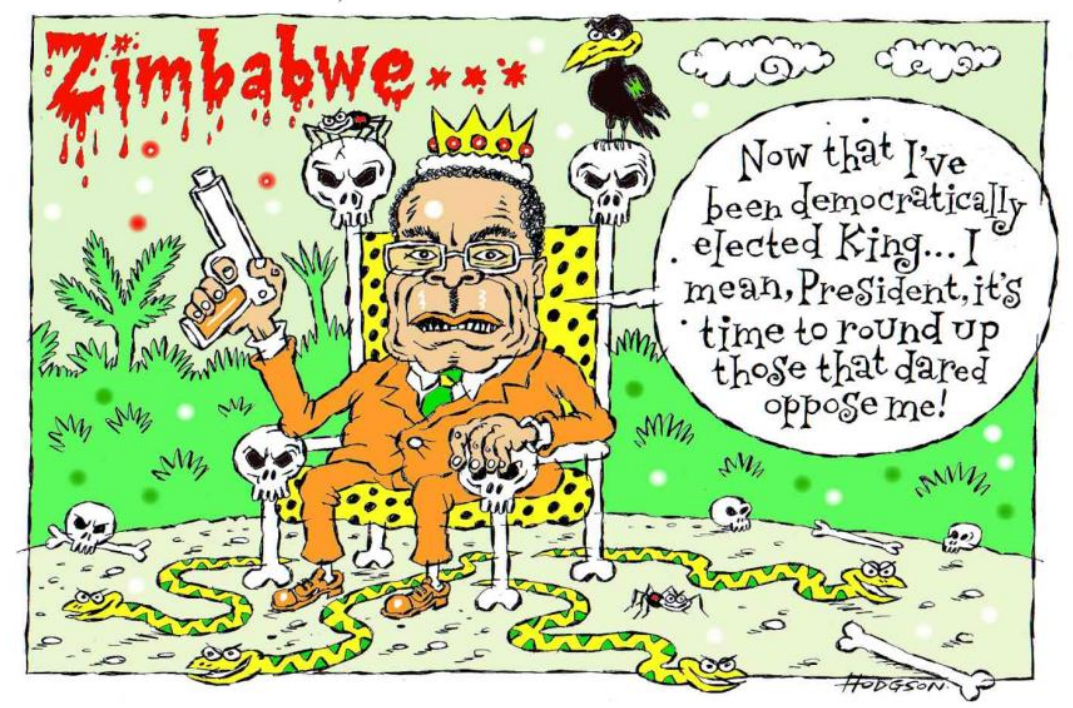

Figure 3. Trace Hodgson, The Dominion Post, 13 August 2013.

Fast forward to 2013 and, in Figure 3, we see cartoonist Trace Hodgson depicting President Mugabe, after the disputed Zimbabwean Election, in a similar way although wearing Western attire, "that quintessential symbol of Englishness, the Savile Row suit" to which Mugabe was so attached (Holland 2008). After all, this is a man who, at different times, had been welcomed into the world's political forums and dined with members of British royalty. Although Hodgson's cartoon was not subject to any complaints to the Press Council, is it inevitable that cartoonists, particularly those with a background in the comic tradition, will consciously or unconsciously reference 
pre-existing racial stereotypes when depicting ethnicity and race? Hodgson would argue that he is "not a racist". If he has any prejudices they are against society's treatment of what he terms "the underdog". He rails against "the tendency to bash the underprivileged, the unemployed, prisoners, druggies" as "if being out of work, poor, young, Maori or on drugs is a crime" (Hodgson 2004a). In response to criticism of his graphic treatment of Maori, for instance, he explains that he is only caricaturing features as he sees them, that he will "have a go at anybody no matter what race, colour or creed they are" (Hodgson 2004b).

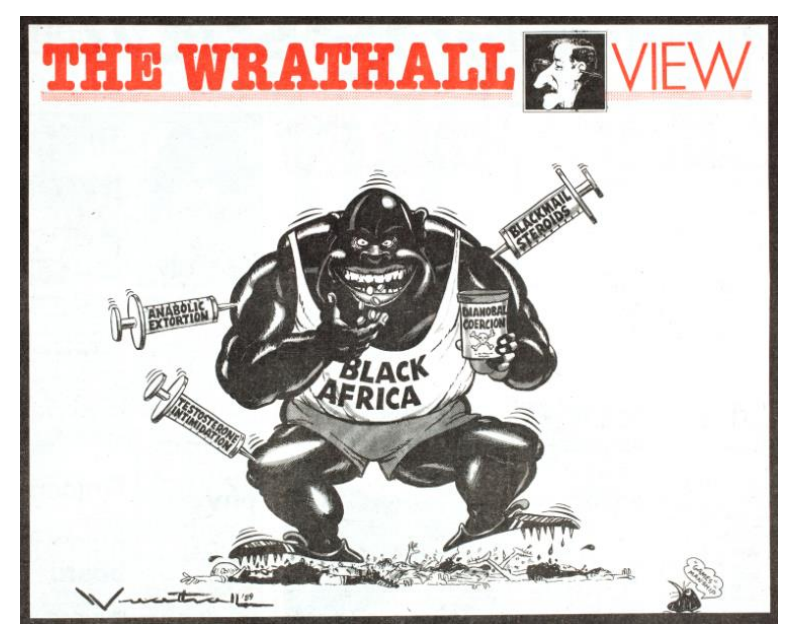

Figure 4. Bill Wrathall, Truth, 30 June 1989.

Caricaturing a politician is a common sport for the editorial cartoonist and most would say that caricaturing an African politician is no different to caricaturing a politician of any race. Misunderstandings can arise when the subject of satire is an individual or group used to personify the situation. Although the intention may be to attack the leader of a country or the policies of institutions or agencies within that country, there are occasions where the graphic approach taken by a cartoonist can be interpreted as discriminating against an entire race or societal group. In the case of another Truth cartoon by Wrathall, published in 1989, the Council upheld the complaint, "judging it to have been racist" (NZPC 1990: 12). The cartoon featured a steroid-inflated, African athlete (see Figure 4), spiked with syringes of "anabolic extortion", "testosterone intimidation" and "blackmail steroid" while simultaneously swallowing "dianobal [i.e. Dianabol] coercion" pills. His running shoes drip blood from the bodies of the Lilliputian sportsmen he spikes underfoot. In the lower right corner, a small everyman Kiwi quips, “Games'-manship". In the cartoonist's explanation, the figure labelled "Black Africa" was "symbolic of [the] power and force, acquired by using sports boycott threats which resulted in destroying international events"; "it was not" he said, "a picture of a black man killing white people". The Council, in its adjudication, conceded that the "intended message of the cartoon ... in itself could not be held offensive" as it "might well be, and often had been, argued". Rather, it was that "the impact of the cartoon came from the figure and this created the impression that black Africa in general was a murdering or trampling monster" which was likely "to stir an emotional response of hatred or contempt for a class of people as a whole" (NZPC 1990: Case 393). So, the point being made was reasonable but the cartoonist's personification of the union of boycotting African nations, in the complainant's words, as a "sub-human monster", posed the risk of 
inciting a racist attitude towards all "black-skinned Africans" (NZPC 1990: Case 393).

The Council's ruling parallels the change occurring in attitudes to race in New Zealand. In the 13 years since the first cartoon complaint and Wrathall's "Black Africa" cartoon, New Zealanders had developed a greater awareness of racism, both at home and overseas. Opposition to the 1981 tour of the Springboks, a South African rugby team, selected again on racial grounds, was described as the "closest ... New Zealand has come to civil war" that century, with the country torn apart by pro-tour and anti-tour protests. As Richards writes, "between a third and a half of the country's entire police force was required to enable test matches to proceed ... the largest ever police operations in New Zealand's history" (Richards 1999b: 5). Still, there would have been many Truth readers disappointed by the boycotts by African nations. The cartoonist's victims are the trampled, white sportsmen who have been denied the opportunity to compete against their esteemed African rivals. In a final comment regarding the "Black Africa" cartoon, the Council noted that "the same degree of offence would be experienced by any group of people so represented and defined by colour, race, religion or national origin" (NZPC 1990: 12).

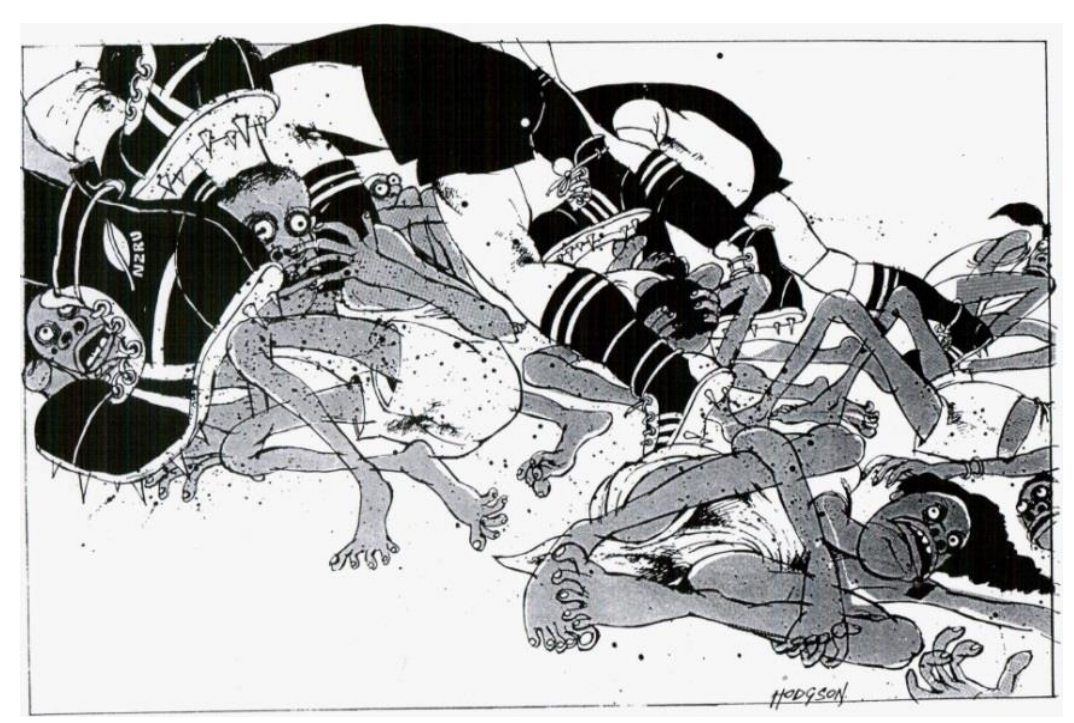

Figure 5. Trace Hodgson, New Zealand Listener, 1986.

Although not subject to a complaint to the Press Council, it is interesting to compare Hodgson's cartoon from three years earlier of the Cavaliers, a group of rebel All Blacks who toured South Africa unofficially (see Figure 5). If we think about the stereotypes of victims and perpetrators, the image of black Africa personified as a perpetrator of injustice is deeply disturbing. However, while few could not be moved by the image of white rugby players mowing down the victims of a cruel apartheid system, the stereotype of the perpetrators -Kiwi blokes whose passion for playing the Springboks has led them to put sport before politics- is more discomforting than offensive. The dominant white culture is shamed rather than dehumanised. 


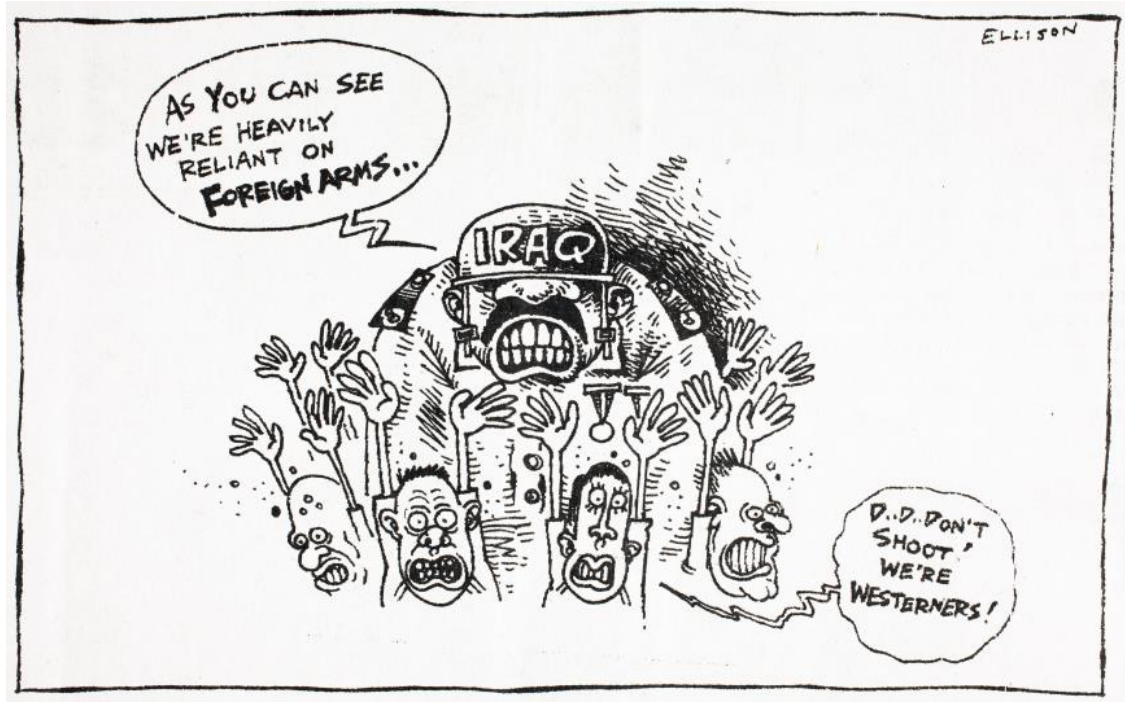

Figure 6. Anthony Ellison, Auckland Star, 20 August 1990.

A similar disparity in scale to that seen in the "Black Africa" cartoon occurs in a cartoon by Anthony Ellison (see Figure 6) in which a snarling beast-of-war in a military helmet labelled "Iraq" threatens to sacrifice a group of small and innocent "Westerners". Ellison plays on the word "arms" to highlight the irony in Saddam Hussein's reliance on foreign-manufactured arms and subsequent employment of Western hostages, arms raised in supplication, as a shield against retaliatory, foreignarmed intervention. Although the "Iraq" figure was a vehicle for personifying Hussein's war-mongering, a representative of HART complained that it was "racially offensive and portrayed the Iraqi people in a light which could only cause hostility and ill-feeling in an obvious tense and dangerous situation" and with New Zealanders among those detained it "was in poor taste". In his opinion, the cartoon "did not identify Hussein as the hostage taker but smeared all Iraqi people". The complaint was not upheld, the Council noting that "the cartoon was a legitimate comment on a situation of immense public concern ... and did not offend against reasonable and generally accepted standards of taste" (NZPC 1991: Case 416).

What makes Ellison's "Iraq" cartoon more acceptable than Wrathall's "Black Africa" cartoon? In both instances, the central figure has been interpreted as denigrating a wider societal group, either "black Africa in general" or "all Iraqi people". Undeniably, skin colour is a factor; the gross stereotype of a steroid-fuelled, black athlete is far more unsettling than if he had been a doped-up, white-skinned athlete. Ugly caricatures of white sportspeople are not unusual. Following New Zealand rugby's fall from grace in 1981, many cartoonists stereotyped players in unflattering ways. A 1982 National Business Review cartoon by Bob Brockie, for example, is memorable for his caricatures of a bunch of slavering, lecherous Kiwi rugby players eager to accept invitations from South African rugby, personified as a hooker posing on a chaise longue labelled "Apartheid", to play either as individuals or part of an international team. Brockie's comment that "racism is probably the most sensitive thing these days ... you have got to treat that rather carefully" suggests that it is unlikely he would ever draw black sportsmen in a similarly derogatory way (Brockie 2003). When it comes to Maori, he says that "we cartoonists endlessly ridicule Pakeha [European New Zealanders] but we' $d$ be in big trouble if we similarly ridiculed Maori” (Brockie 2014). 
It might be also that on a subconscious level, the scale and grotesqueness of "Black Africa" references Western history's archetypes of evil, the forces of darkness against all that is good, white and pure. The ferocity expressed in the cartoon is disturbing and extreme given the issue. Compared with the Iraq cartoon (Figure 6), the boycotting of sports events by a group of black African nations is not quite commensurate with Hussein's threat to the lives of fellow New Zealanders. In contrast to the hyperrealism of "Black Africa", the "Iraq" figure is a machine-like, militaristic robot, almost a fake-scary, comic-book character. The editor, responding to the complaint against Ellison's cartoon, argued that "most New Zealanders would find [Hussein's use of western hostages as a war weapon] ... racist, offensive and hostile" (NZPC 1991: Case 416). But, although, as the Council notes "'no war had begun in the Gulf", the risk of war was in the wind which would likely legitimise a gloves-off approach by a cartoonist in dealing with a belligerent dictator. The complainant also alluded to war, commenting that the cartoon was "reminiscent of the 'yellow peril' type posters published by the Allies during the Second World War" (NZPC 1991: Case 416).

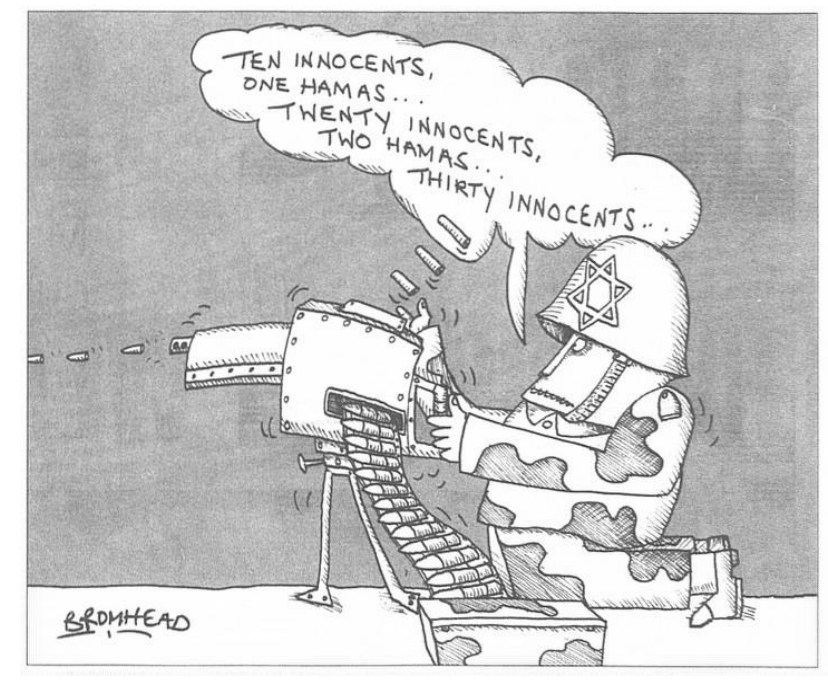

Figure 7. Peter Bromhead, Sunday Star Times, 11 January 2009.

\subsection{Inaccuracy and discrimination: complaints of anti-Semitism}

Strong, emotive analogies, such as the reference to "yellow peril-type posters", often appear in complaints of racism. In the first complaint of anti-Semitism received by the Press Council, the complainants -Kiwis for Balanced Reporting on the Middle Eastargued that the figures used in a cartoon by Peter Bromhead (see Figure 7) to suggest more innocent people had been killed than members of Hamas were inaccurate and "not a justifiable or harmless exaggeration ... but an out-and-out untruth akin to 'Jews kill Christian babies and drink their blood' claims made by anti-Semites over the centuries". The cartoon, published in January 2009, features an Israeli soldier, identified by the Jewish Star of David on his helmet, firing a mounted automatic machine gun and counting off his victims as bullets are continuously fed from the connecting ammunition belt: "Ten innocents, one Hamas... twenty innocents, two Hamas... thirty innocents...". The complainants said that "Israeli and United Nations authorities ... had found the opposite ... in fact, more Hamas had been killed ...". The 
complaint was not upheld. The editor asserted that cartoonists are "employed to express their opinions" and that the cartoon had been "published on a page marked "Comment and Review"'. That is, the cartoon was within the guidelines expressed in principle 4 of the Press Council's Statement of Principles: "A clear distinction should be drawn between factual information and comment or opinion ... [cartoons] are understood to be opinion" (NZPC 2009). The Council agreed, however, as far as accuracy "in relation to the figures cited in the cartoon" it was "impossible to resolve" but the "cartoonist is entitled to make the point that civilian Palestinians of Gaza suffered heavy losses" (NZPC 2009: Case 2067). Complainants citing inaccuracy in a cartoon often refer to the Press Council's principle 1, which states: "Publications should be bound at all times by accuracy, fairness and balance, and should not deliberately mislead or misinform readers by commission or omission" (NZPC 2009). The Council's ruling corresponded to its decision regarding another complaint of inaccuracy against a New Zealand Herald cartoon by Bromhead, published in January 2007, in which it noted that readers "are assumed to understand that a cartoonist will not necessarily be relying on actual events", that "a representational situation" can be used "to give rise to the satirical point" and that "readers do not look to cartoons for "news"' (NZPC 2007: Case 1088).

The contravening of the Press Council's principle 1 (Accuracy) and principle 6 (Discrimination) formed the basis of one of two complaints received against a Malcolm Evans cartoon, published in The Press on 9 April 2012. The subject of the two-panel cartoon is the expansion of Jewish settlements on the West Bank. The satire is in a form of word play: in the top panel, US President Obama is shown pointing a finger at Israeli Prime Minister Netanyahu and saying, "I'm starting to doubt Israel's commitment to a [peace] settlement!"; in the lower panel, Netanyahu is shown with a map pointing out settlements which are identified by the symbol of the Star of David. "That's silly!" he says. "Look we're committed to [housing] settlements here, here, here...". In a thought bubble from Obama are the words, "Men are from Mars... Zionists are from Uranus!" The complainant alleged that the cartoon was "antiSemitic because it compared Jews with human excrement or flatulence" and "inaccurate in questioning Israel's commitment to a peace settlement". He argued that the word "Zionist" was "a pejorative term for 'Jew' and, therefore, the cartoon is critical of the whole Jewish people and not simply those who support the expansion of settlements". In response, Press editor Andrew Holden disputed that the cartoon was anti-Semitic. With regard to the tastelessness of Obama's thought speech, he observed that while "the humour is clearly scatological, the most that could be read into it is that US President Obama 'thinks' that Netanyahu and his political supporters are assholes" (NZPC 2012: Case 2268).

The Council did not uphold the complaint on the grounds of accuracy, stating that it could not "rule on whether or not it is accurate to say Israel is committed to a peace settlement", nor on a "a single definition of Zionist", but it believed it was clear in the cartoon that "Zionist" referred "to those supporting the extension of settlements in the occupied territories". That is, although it clarified that principle 1 "referring to accuracy does not only apply to factual articles", that the "facts on which opinion or commentary is based also need to be accurate", it considered that there was a sufficient basis of fact supporting the essence of the cartoon. Further, in response to the complaint that the cartoon was "racial in content, not political", the Council stated that its principle 6 "relating to discrimination does not restrict content that refers to religion or race ... [that] these are legitimate topics where they are relevant and in the public interest, and as long as there is no gratuitous reference" (NZPC 2012: Case 
2268). Thus, as demonstrated by the three foregoing rulings, although cartoons are "understood to be opinion", the Council is concerned that the facts informing the opinion are accurate and with regard to issues of religion and race "publications may report and express opinions in these areas" (NZPC 2009). As the Council noted, with respect to content that refers to the latter, it set "a high bar ... to protect freedom of expression" and its principles gave "scope to cartoonists to express very strong, even unpopular viewpoints" (NZPC 2012: Case 2268).

Nonetheless, many are hesitant to venture into what might be called "sacred ground", a concern which is shared not only by New Zealand cartoonists. Australian cartoonist Bruce Petty observed that it was very hard to criticise the military behaviour on either side ... without drawing in the Holocaust factor, and ... the whole history of Jewish persecution" (Thompson 2004). British cartoonist, Martin Rowson, puts it more bluntly: "The equation of Israel and Jewry has proved to be a brilliant tactic to disarm Israel's critics, simply by calling any criticism of Israel and its actions anti-Semitic" (Rowson 2009: 53). As with many complaints, the scale of offence taken can deflect from the issue being cartooned.

Malcolm Evans, who would fiercely defend himself against accusations that he is anti-Semitic, is one of the few cartoonists who will not give up on the Palestinian cause. His frequent focus on this issue led to dissension with his former New Zealand Herald editor, Gavin Ellis, who was concerned that it was leading "to the exclusion of other subjects he should have been dealing with" (Ellis 2012). Evans believes that an "editor has the absolute right to reject [his] cartoons ... but no right to dictate what those cartoons might be" (Brown 2003). A further source of contention was "Evans' use of religious symbols to depict political entities which flouted editorial direction. It was Evans' belief that he was not subject to such direction that contributed to him losing his job" (Ellis 2014). A cartoon in which Evans substituted the Star of David for the second "a" in the word "Apartheid", graffiti'd on the wall of a bombed-out Palestinian township, inadvertently slipped through the editorial net. The symbol was interpreted by a number of readers as referring to all Jewry rather than to the State of Israel and gave rise to a number of complaints which ultimately lead to mediation by the Race Relations Commission (Lawrence 2006). Ellis believes that "people have an inalienable right to hold their religious symbols as precious". He cited another situation where he "took issue with a cartoon about Syria in which Evans had drawn the star and crescent of Islam morphing into a Stalinist hammer and sickle" (Ellis 2012). "Religious symbolism is not only the symbols that we use", he says, "but the prohibitions that are so deeply held that to transgress is to fundamentally challenge core belief. For example, the non-portrayal of Muhammad $\ldots$ is fundamental to Islam". For this reason, he would not have republished the Danish cartoons if he had been working at the Herald at the time of the controversy (Ellis 2014).

The Press Council's so-called high bar to protect freedom of expression does not necessarily influence editorial decisions on "what meets ... ever-changing and evolving notions of decency and acceptability" (NZPC 2006: Case 1055). These tend to be determined by understanding the parameters of readership taste and tolerance. Ellis expressed this when he described his New Zealand Herald readership as "diverse" but that "society generally had bounds to what is acceptable ... [and] you just need to know where those boundaries lie" (Ellis 2012). 


\subsection{Complaints against racial stereotyping of Maori and Polynesian}

Closer to home, problems in Maori or Polynesian communities are our own "sacred ground". Many cartoonists interviewed expressed reluctance to address troubling social issues relating to these groups to avoid being accused of racism. In the South Island, Garrick Tremain and Al Nisbet are two who have been undeterred by criticism.

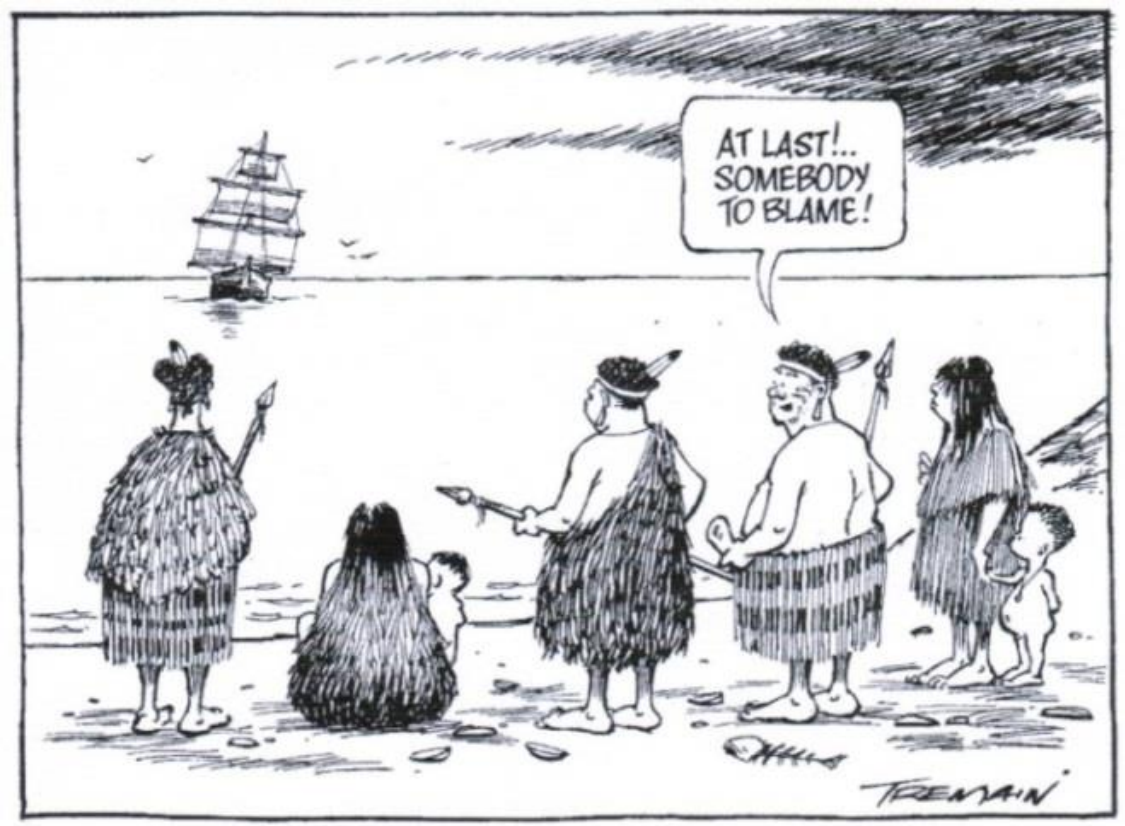

Figure 8. Garrick Tremain, Otago Daily Times, 31 August 2000.

Reacting to a number of complaints regarding Tremain's cartoons in the 1990s, former Race Relations Commissioner Rajan Prasad expressed concern over "the constantly negative image of Maori presented" and asked that Tremain "take whatever positive action ... to promote race relations and ... desist from popularising the stereotyped images" (The Press 1998: 5). Tremain replied that he had never lampooned anyone for their race. Furthermore, he did not believe that "cartoons lead and fashion ... attitudes" but just, "the opposite". They "follow and reflect attitudes and by doing so with humour they diffuse public anger" (The Press 1998: 5). He explains the huge popularity of his Otago Daily Times cartoon (see Figure 8), published August 2000, as being due to "public exasperation" over various Maori leaders who were in what he described as "full grievance mode over the ills of colonisation" (Tremain 2008). In the cartoon, a group of Maori in the common stereotype of traditional dress are gathered on a foreshore observing the arrival of a European sailing ship. "At last!" exclaims one of them. "Somebody to blame!" At the time, there was disquiet expressed in some sectors of the population over Treaty of Waitangi claims. Tremain observed that "any cartoon ... misconstrued as racist is more likely to cause editorial alarm in northern papers than southern ones" (Tremain 2012). This could be a factor of population demographics. The 2006 Census records that $87 \%$ of Maori and $93 \%$ of Pacific people were living in the North Island, with $67 \%$ of the latter living in the Auckland region (Statistics NZ 2006a; 2006b). In Wellington, perhaps the capital of political correctness, a 2004 survey by UMR Research revealed that there was a greater understanding of, and commitment to, the 
Treaty of Waitangi than elsewhere in New Zealand (State Services Commission: 2004).

\subsection{Diverse culture and beliefs: New considerations on where the boundaries lie}

With an increasing number of non-European immigrants settling in New Zealand -for instance, Asian ethnic groups have almost doubled in size since 2001 (Statistics NZ 2013) - there are many more people living here today from cultures where there is not the same tradition of provocative graphic satire. Misunderstandings occur when there is little appreciation of the role and language of cartoons. For many ethnic communities, the Press Council's "high bar" is a source of frustration and incomprehension. The Council is seen as having "no teeth". In the opinion of Selva Ramasami, a member of The Hindu Council of New Zealand, it is better to complain to the Race Relations Commissioner (Ramasami 2014). But for the Commissioner to rule that a cartoon was "unlawful", it would need to be considered, under the terms of Section 61 of the Human Rights Act, as "threatening, abusive or insulting and such that it is likely to excite hostility against or bring into contempt a group of people on the grounds of their colour, race, national or ethnic origins" (Human Rights Act 1993).

The re-publication of the Muhammad cartoons, first published in the Danish newspaper Jyllands-Posten, by three New Zealand newspapers, on the grounds of "solidarity and supporting press freedom" (NBR 2006), clarified further where the HRC stood on this issue. Tim Pankhurst, editor of one of the papers, describes being "very careful about the context". For instance, the story was not run on the front page but inside on the World pages; the intention was to explain "this is what the fuss is about; this is why there are protests and embassies being burned". He did not "see it as a gratuitous insult to Islam or in any way trying to provoke the Muslim community" (Pankhurst 2011). Although the scale of the furore was nothing like that overseas, the publication provoked what was described as "strong interfaith and government condemnation, a public protest demonstration, and considerable general public opposition" (HRC 2012). The Race Relations Commissioner convened a meeting of 15 media representatives and religious leaders at which it was resolved "to support the importance of freedom of the media" while acknowledging that it came with responsibilities, "which include sensitivity to diverse cultures and beliefs". The resolution was not lost on the Press Council; a commentary headed "Cartoons" in the Council's $201240^{\text {th }}$ Report, concludes:

The storm [over the publication of the Danish cartoons] was short-lived, but the question of how far, in a multicultural world, the use of a form of visual comment, which has evolved in one cultural tradition, is appropriately used in commenting on a very different culture remains and is not entirely straightforward. This, not to mention threats of civil disorder or violence, or issues of our relations with other countries, would raise a whole new set of questions both for editors and for the Press Council.

(NZPC 2012: 9) 


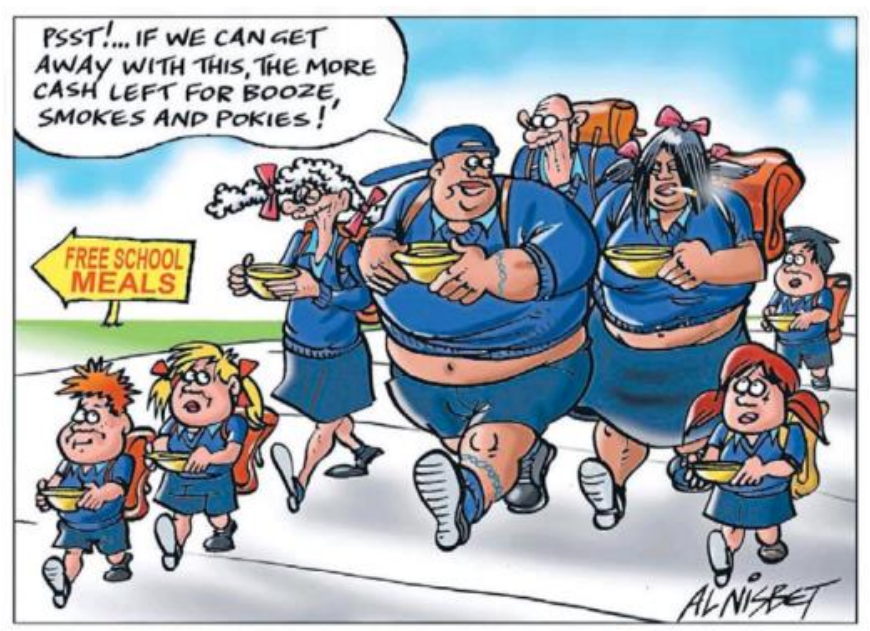

Figure 9. Al Nisbet Marlborough Express, 29 May 2013.

\subsection{Nationwide condemnation of cartoons: An indication of current societal attitudes}

Finally, two cartoons by Al Nisbet in 2013 were the subject of a number of complaints to the Race Relations Commissioner. Not since the re-publication of the Danish cartoons has a cartoon story created so much attention in the national news. So it is valuable to explore possible reasons. In the first (see Figure 9), the cartoonist, reacting to the government's announcement of a programme of free breakfasts in primary schools, took the angle that some welfare-dependent families budget poorly and spend money on alcohol, cigarettes and gambling rather than on food for their kids. The parents and grandparents have donned school uniforms in a bid to qualify for free milk and Weet-bix. Although the family's ethnicity is diverse, the catalyst for the complaints was the dark-skinned, overweight parents who lumped together dominate the white characters: the four small children and the two wrinkly grandparents. Nisbet initially drew the family white but when he heard that the programme would begin first in the Northland region, where there is a large population of Maori and Pacific people, he "darkened the two central characters' skin and lips to balance the ledger" (Nisbet 2013). Race Relations Commissioner, Susan Devoy, stated that it was "glaringly obvious that the cartoon portrayed Maori or Pacific as the butt of its attempted humour" and "such negative stereotypes" used in this way is "insulting and derogatory in the extreme" (Manhire 2013).

Was the dissemination through social media a factor? The first of the two cartoons was published in the Marlborough Express where Nisbet was standing in for their regular cartoonist. It seems the cartoon was picked up and forwarded on Facebook and from there whizzed through the ether to countless smart phones, iPads and personal computers. Editor, Steve Mason, said "most of the outcry had been national, rather than from his readers" (Dally 2013). A similar rapid transmission occurred with the second cartoon, on the same topic, published the following day in The Press in Christchurch. Nisbet expressed surprise at the uproar as he had done "a hell of a lot worse" (Dally 2013). For many receiving the images via social media, it may have been their first encounter with Nisbet's harsh, uncompromising, graphic style. He draws Pakeha in an equally unflattering manner. As he says, "I tend to stereotype everyone ... [and] draw people grotesquely because I think people are 
grotesque" (Nisbet 2007). The cries of "callous", "racist" and "poor-bashing" by the disgusted, outraged and offended masked Nisbet's intended message which was not about race but, in his words, about those who complain "about poverty" and "blow their money on booze, fags and pokies" (Daly 2013). Twitter-users described the cartoons as "an embarrassment to New Zealand [which] harked back to a racist past" (TV One News 2013). Could there be an element of Pakeha guilt here? A recent study of a group of 13-14 year old Auckland school pupils, revealed that Pakeha teens "reported feeling shame about 'the bad things my ethnic group has done in the past ... that don't make me proud". Some resented "the ever-present stereotype that Paheka were all racist" (Webber et al. 2013: 49). Is this feeling equally prevalent with their parents? It is discomforting to confront the fact that colonisation, including the unlawful appropriation of Maori land, has impacted on the social and economic wellbeing of Maori people.

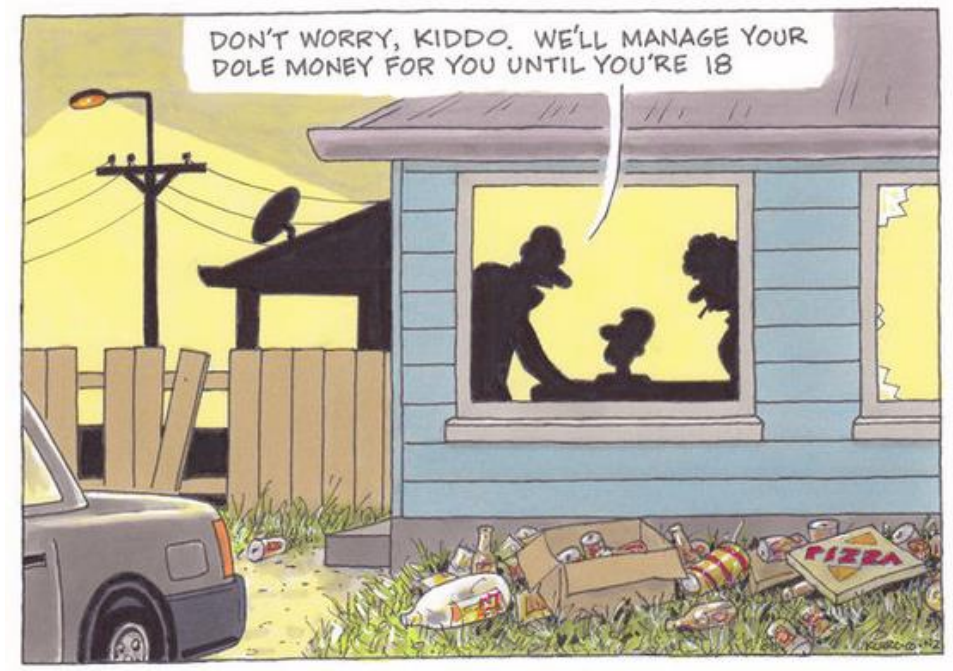

Figure 10. Klarc Northern Advocate, 20 August 2011.

Would the same offence have been taken if his characters had been Pakeha? Race is unspecified in a cartoon (see Figure 10) by Klarc (Laurence Clark) which was drawn in response to recommendations by an HRC Welfare Working Group that beneficiaries under the age of 18 should be required to have parents or guardians manage their benefit (HRC 2011). In choosing a night-time domestic scene with his characters framed in a lit window, all we can see are the silhouettes of a man and a woman standing over a smaller, seated figure. "Don't worry, Kiddo", says the father/guardian. "We'll manage your dole money for you until you're 18." With the sky dish on the roof, the heap of discarded drink cans, bottles and fast-food packaging tossed on the ground outside the window and the cigarette hanging from the woman's mouth, Klarc is sending a similar message to Nisbet's but not restricting the problem solely to Maori or Pacific people. As he says, the cartoon is "definitely NOT about race ... plenty of Pakeha examples on this score" in the Northland region (Clark 2014).

Journalists often refer to their role as speaking truth to power. ${ }^{2}$ But what about cartoons that speak truth about the powerless? We are used to cartoonists attacking politicians, the rich and the powerful. But when they focus on those at the bottom of society, it feels like bullying. Australian Michael Leunig suffered a similar backlash from working mothers with his cartoon on the thoughts of a stay-at-crèche baby. $\mathrm{He}$ 
believes one of his functions as a cartoonist is "to give air to what people are whispering" (Lowe 2000: 6). Is Nisbet not saying "the unsayable" (Seymour-Ure 2003: 231)? The attitudes held by some people may seem backward and outdated to others in our society but is it not better that all opinions are in the open rather than left to fester? Where many argue Nisbet's cartoon is promoting a negative stereotype, there are others working in education and social services who, off the record, have said that he is expressing a reality.

Cartoons by their very nature take a black and white view. Unlike editorials, they cannot say "on the other hand", but they may soften the angle they have taken one day by choosing a different approach the next. The question is whether this balancing out of opinion lessens the effect of a cartoon that is perceived as discriminatory? Moreover, as Paul Rishworth (2003: 21) writes, the harm might be "not so much in the attitudes engendered in others as in the erosion of self-worth in the victims, their withdrawal from society and the resultant inequality".

\section{Conclusion}

The very first cartoon complaint received by the Press Council was in 1976. It was against the racial stereotyping of a respected African leader. The complaint was not upheld. Thirteen years later, a complaint against the image of a drug-fuelled, black African sportsman stomping over puny, white athletes was upheld. In the interim, New Zealand's increasing awareness of racism at home and overseas reached a critical point with nationwide protests against the 1981 Springbok Tour. By the early 1990s, South Africa's apartheid system had been dismantled. Around this time, a number of complaints of negative racial stereotyping of Maori in cartoons by Tremain were made to the Race Relations Commission. Many cartoonists tend not to address troubling social issues relating to Maori and Pacifica in order to avoid accusations of racism. Similarly, from the early 2000s, caution is expressed over commenting on the Israeli-Palestinian conflict with some cartoonists endeavouring a balance of both viewpoints in a single cartoon.

Different readers will interpret the language of cartoons in different ways. As awareness of discrimination in society has grown so it seems that there is a greater sensitivity to the way in which cartoonists use graphic devices such as metaphor, stereotyping and personification with accusations of racism occurring where there may not have been any racist intent. Furthermore, the visual shorthand of representing a nation state through the use, in isolation, of a religious symbol associated with that state runs the risk of causing offence on various grounds.

The furore in 2006 over the republication of the Danish cartoons stimulated discussion about the responsibility of a free press in an increasingly diverse society. Six years on, the widespread complaints against two cartoons by Al Nisbet considered racist provide a valuable case study of where societal attitudes towards race may rest today and how prevailing attitudes may impact on editorial decision-making and the cartoonist's right to freedom of expression. Why did these cartoons incite such intense debate in both mainstream and social media? It is possible that Nisbet's two darkskinned Maori or Polynesian parents dwarfing other white family members unconsciously triggered archetypes of bad versus good. But, it is more likely that current sensitivity to racial discrimination, or any suggestion of "poor-bashing", prompted a small portion of a vocal, educated class to react in defence. For many, social media offered the opportunity for an immediate, impassioned response which 
grew in censorious power as others shared online their outrage. Since the outcry over the cartoons, several cartoonists have suggested that their editors are more cautious; the word "cowardly" was even used. For some editors, the possible risk of nationwide censorship via social media may influence editorial decisions on "decency and acceptability" (NZPC 2006: Case 1055). The concern that negative stereotypes might embed discriminatory attitudes and cause harm to a particular group in society is a legitimate one. But this concern needs to be weighed against the role of a cartoonist in highlighting injustice and exposing the weakness or hypocrisy in society. Why employ a court jester if you plan to gag him? Is the cartoonist not simply holding up a mirror to society? Further, do we want all our cartoonists to speak with a single voice or should they be free to reflect all aspects of society and opinions from the sophisticated liberal to the deeply-entrenched red-neck? Nisbet agrees with Tremain's comment that: "Cartoons don't lead the news; they reflect the news. It is one part humour and part a reflection of what people think" (Harvey 2003). "Because after all" says Nisbet, "you are relying on the news before you can do a cartoon ... and sometimes it is the masses' opinion, what everyone's saying ... you can almost feel the energy out there on an opinion so you might take that opinion" (Nisbet 2007). Although cartoons are able to say what cannot always be said in other media, in general they are no different. Paul Spoonley (1990:31) writes, "if the media are racist, then it will be because the wider society is racist". To conclude, surely, it is better that we are aware of racist attitudes in society in order to address them. As an editorial from The Dominion, as far back as 1988, sagely states, "Good race relations will never develop out of force to silence. Extreme and offensive views will not disappear because they are unspoken. At least if they are freely expressed they can be challenged and countered".

\section{Acknowledgments}

I wish to thank all the cartoonists for permission to publish their cartoons in this paper. The one exception is Bill Wrathall, now deceased. Despite best efforts, it has not been possible to locate the copyright holder of his cartoons.

\section{Notes}

1 Among the most eagerly anticipated events at the Montreal Olympics was the expected 1500-metre showdown between John Walker of New Zealand and Filbert Bayi of Tanzania. But, with Tanzania the first African nation to announce that it would boycott the Games, Bayi would not compete. More than 20 African nations stayed away causing a massive reorganisation of scheduled events (NZ History 2012).

2 The phrase "Speak Truth to Power" comes from a 1950's American Friends Service Committee (Quaker) pamphlet.

\section{References}

Brockie, B. (2003). 'Interview with S. E. Foster'. Wellington, August, pp. 21-29. Brockie, B. (2014). Personal communication S. E. Foster. July 15. 
Brown, R. (2003). 'Interview Malcolm Evans'. Media Watch, Radio New Zealand National, August 17.

Clark, J. (Race Relations Conciliator, 1992-1995). 'What's wrong with stereotypes?' Pamphlet. Wellington: Race Relations Office, Human Rights Commission.

Clark, L. (2014). Personal communication with S. E. Foster. July 1.

Cook, M. (2012). 'Africa and New Zealand - Politics, apartheid and sport: 1940s to 1990s', Te Ara - The Encyclopedia of New Zealand, updated 16-Nov-12. URL: http://www.TeAra.govt.nz/en/photograph/35908/political-leaders-visit-ofpresident-nyerere-to-new-zealand [Accessed 1 July 2014].

Dally, J. (2013). “"Racist” cartoon slammed'. Marlborough Express, 30 May.

Daly, M. (2013). 'Cartoons no joke for the poor says Devoy'. The Dominion Post, 31 May.

Ellis, G. (2012). Interview with S. E. Foster. Auckland, July 12.

Ellis, G. (2014). Personal communication S. E. Foster. July 16-31.

Gustafson, B. (2000). His Way: A Biography of Robert Muldoon. Auckland: Auckland University Press.

Harvey, C. (2003). 'Cartoonist drawn into NZ furore'; [1 Preprints Edition]. New Zealand correspondent. The Australian, September 25, p.B.03.

Hodgson, T. (2004a). Paper presented under cartooning session 'Drawing the Line'. The Press Christchurch Writers' Festival, September 17.

Hodgson, T. (2004b). Interview with S. E. Foster. Nelson, November 25.

Holland, H. (2008). 'What makes monster Robert Mugabe tick?' The Telegraph, 28 June.

Human Rights Act (1993). ‘61 Racial disharmony’. Parliamentary Counsel Office New Zealand Legislation. URL: http://www.legislation.govt.nz/act/public/1993/0082/latest/DLM304643.html [Accessed 30 June 2014].

Human Rights Commission Newsletters (2012). URL: http://www.hrc.co.nz/newsletters/diversity-action-programme/nga-reotangata/2012/09/publication-of-danish-cartoons-by-nz-media-showed-wayforward/ [Accessed 25 June 2014].

Human Rights Commission Welfare Working Group Recommendations (2011). URL: http://www.hrc.co.nz/wp-content/uploads/2011/12/Welfare_Working_Group_Recommendations_August_2011.html [Accessed 30 June 2014].

Lawrence, J. (2006). 'Address by Jeremy Lawrence, Senior Rabbi of the Great Synagogue in Sydney'. Australian Jewish Times.

Lowe, R. (2000). 'Cartoonist unrepentant over crech controversy', Sydneyside; [2 Edition]. Waikato Times, 15 May, p.6.

Maharey, S. (1990). 'Understanding the mass media', in Spoonley, P. \& Hirsh, W. (eds.), Between the Lines: Racism and the New Zealand Media, Auckland: Heinemann Reed, pp.13-25.

Manhire, T. (2013). 'At last, Devoy speaks out on race'. New Zealand Herald, 31 May.

Merriam-Webster Dictionary (2014). Anti-Semitism. URL: http://www.merriamwebster.com/dictionary/anti-semitism [Accessed 19 June 2014].

National Business Review (2006) 'Dominion Post to publish controversial cartoon'. 3 February. 
New Zealand History (2012). 'The Montreal Olympics boycott'. URL: http://www.nzhistory.net.nz/media/photo/montreal-olympics-boycott (Ministry for Culture and Heritage) [Accessed 20 December 2012].

New Zealand Press Council Cartoon Complaints:

Case 918. (2003). N. Brailsford against The Dominion Post

Case 684. (1998). New Zealand Shooting Federation against the Evening Post

Case 1055. (2006). E. Sloan against The Dominion Post

Case 69. (1976). L. Trainor against New Zealand Truth

Case 393. (1990). African Information Centre against New Truth

Case 416. (1991). D. Cuthbert, National Treasurer, HART against Auckland Star

Case 2067. (2009). Kiwis for Balanced Reporting on the Mideast against Sunday Star Times

Case 1088. (2007). T.F.W. Harris against New Zealand Herald

Case 2268. (2012). C. Morey against The Press

New Zealand Press Council. (1990) 'The Eighteenth Report of the NZ Press Council'. Wellington.

New Zealand Press Council. (2009). 'Statement of Principles and Complaints Procedure' (Two-fold, single-sided leaflet). Wellington.

New Zealand Press Council. (2012). '40th Report of the New Zealand Press Council'. Wellington.

New Zealand Press Council (2014). 'Statement of Principles'. URL: http://www.presscouncil.org.nz/principles.php [Accessed 30 June 2014].

Nisbet, A. (2007). Interview with Susan E. Foster. Christchurch, July 4-5.

Nisbet, A. (2013). 'Stereotypes ensure quick grasp of the issue'. The Dominion Post, 4 June.

Pankhurst, T. (2011). Interview with Susan E. Foster. Wellington, July 12.

Ramasami, S. (2014). Personal communication with S. E. Foster. July 17-18.

Richards, T. (1999a). Dancing on Our Bones: New Zealand, South Africa, Rugby and Racism. Wellington: Bridget Williams Books.

Richards, T. (1999b). 'From the eye of the storm: rugby's power to divide and embattle', in Foster, S. E. (ed.), Guts \& Glory: an Exhibition of Rugby Cartoons. Catalogue, Wellington: New Zealand Cartoon Archive Trust, pp. 5-7.

Rishworth P. (2003). 'The right to freedom of expression.' Research paper written for the Human Rights Commission. URL: http://www.hrc.co.nz/hrc_new/hrc/cms/files/documents/26-Oct-2010_10-04-

12_Right_to_freedom_opin_and_express_draft.html [Accessed 25 June 2014].

Rowson, M. (2009). Giving Offence. London: Seagull Books.

Seymour-Ure, C. (2003). Prime Ministers and the Media: Issues of Power and Control. Malden, MA: Blackwell Publishing.

Spoonley, P. (1990). 'Racism, race relations and the media', in Spoonley, P \& Hirsh, W. (eds.), Between the Lines: Racism and the New Zealand Media, Auckland: Heinemann Reed, pp. 26-37.

State Services Commission (2004). 'Treaty of Waitangi Awareness Research - A Qualitative and Quantitative Study'. Conducted by UMR Research in March 2004. https://www.ssc.govt.nz/treaty-awareness-research [Accessed 26 June 2014].

Statistics New Zealand (2006a). 'Census QuickStats about Maori location'. URL: http://www.stats.govt.nz/Census/2006CensusHomePage/QuickStats/quickstatsabout-a-subject/maori/location-te-wahi.aspx [Accessed 26 June 2014]. 
Statistics New Zealand (2006b). 'Census QuickStats about Pacific peoples'. URL: http://www.stats.govt.nz/Census/2006CensusHomePage/QuickStats/quickstatsabout-a-subject/pacific-peoples.aspx [Accessed 29 June 2014].

Statistics New Zealand (2013). 'Census QuickStats about national highlights'. URL: http://www.stats.govt.nz/Census/2013-census/profile-and-summaryreports/quickstats-about-national-highlights/cultural-diversity.aspx [Accessed 25 June 2014].

Television One News (2013). 'Cartoon prompts call for racism threshold change'. 30 May.

Templeton, M. (1998). Human Rights and Sporting Contacts: New Zealand Attitudes to Race Relations in South Africa 1921-94. Auckland: Auckland University Press.

The Dominion. (1988). 'Facing real race issues', September 7.

The Press, News Review. (1998). 'Drawing fine distinctions', June 22, p.5.

Thompson, P. (2004). 'Interview Bruce Petty in "Big Ideas" programme. Australian Broadcasting Corporation (ABC): The Wisdom Interviews'. Broadcast Sunday 8 February.

Tremain, G. (2008). 20 Years of Garrick Tremain Politics from the Pen of a Leading Cartoonist. Auckland: New Holland Publishers.

Tremain, G. (2012). Personal communication S.E. Foster. 30 October.

Webber, M., McKinley, E. and Hattie, J. (2013). 'The importance of race and ethnicity: An exploration of New Zealand Paheka, Maori, Samoan and Chinese adolescent identity.' New Zealand Journal of Psychology, 42 (1), p. 49.

Yska, R. (2010). Truth: The Rise and Fall of the People's Paper. Nelson: Craig Potton Publishing. 